\title{
Editorial: From Exceptional Cases to Everyday Abuses: Labour exploitation in the global economy
}

\author{
Joel Quirk, Caroline Robinson, and Cameron Thibos
}

Please cite this article as: J Quirk, C Robinson, and C Thibos, 'Editorial: From Exceptional Cases to Everyday Abuses: Labour exploitation in the global economy', Anti-Trafficking Review, issue 15, 2020, pp. 1-19, https://doi.org/ $10.14197 /$ atr.201220151.

We are living through an unprecedented global crisis due to the effects of the COVID-19 pandemic. Governments have closed their borders, heavily restricted commercial activities, and instructed people to shelter in their homes. As a result of these measures, hundreds of millions of workers have been deprived of their usual incomes. It has been estimated, for example, that 40 million jobs have been lost in the United States and 122 million in India. ${ }^{1}$ While many governments have devoted resources to cushioning the effects of the pandemic, most efforts have narrowly focused upon their own citizens, leaving many migrant workers stranded far from home with little or no support. The crisis has also had a profound effect upon global supply chains. Workers and factories producing clothes for major fashion labels have not only lost income, but have also seen the cancellation of orders that were already in process. $^{2}$ In May 2020, it was reported that suppliers in Bangladesh had 'lost out on more than $\$ 3$ bn in payments for T-shirts, shoes and designer dresses already produced or sourced'. ${ }^{3}$

1 L Aratani, 'US Job Losses Pass 40m as Coronavirus Crisis Sees Claims Rise $2.1 \mathrm{~m}$ in a Week', The Guardian, 28 May 2020, https://www.theguardian.com/business/2020/ may/28/us-job-losses-unemployment-coronavirus; N Inamdar, 'Coronavirus Lockdown: India jobless numbers cross 120 million in April’, BBC, 6 May 2020, https://www.bbc.com/news/world-asia-india-52559324.

2 M Anner, Abandoned? The impact of Covid-19 on workers and businesses at the bottom of global garment supply chains, Center for Global Workers' Rights, 27 March 2020, https:/ /www. workersrights.org/wp-content/uploads/2020/03/Abandoned-Penn-StateWRC-Report-March-27-2020.pdf.

3 P Nilsson and E Terazono, 'Can Fast Fashion’s \$2.5tn Supply Chain Be Stitched Back Together?', Financial Times, 17 May 2020, https://www.ft.com/content/62dc687ed15f-46e7-96df-ed7d00f8ca55.

This is an open-access article distributed under the terms of the Creative Commons Attribution License (CC-BY). Under the CC-BY license, the public is free to share, adapt, and make commercial use of the work. Users must always give proper attribution to the authors and the Anti-Trafficking Review. 
This Special Issue of the Anti-Trafficking Review was conceived long before anyone had heard of COVID-19, yet its effects have brought many of the pre-existing trends that we were hoping to explore within its pages into sharp relief. First and foremost, it has become clear that the burdens associated with the pandemic have fallen much harder on some categories of people than others. Familiar divisions associated with inequality, gender, race, discrimination, citizenship, and occupation have all played intersecting roles. In addition, we have also seen how companies benefit and workers suffer from specific labour practices. Thanks to subcontracting, outsourcing, and other strategies, many companies have insulated themselves from direct responsibility for their workforce, so when COVID-19 emerged they found it relatively easy to walk away.

A number of recent developments associated with the pandemic can be traced back to the overall design and operation of the global economy. As we explore in this Special Issue, recent decades have been defined by a sustained effort by political and economic elites to depress wages, working conditions, and institutional protections, with a recurring emphasis on deregulation, selfregulation, privatisation, subcontracting, and outsourcing. Other popular strategies have involved moving-or threatening to move-activities to other jurisdictions, and/or recruiting migrant workers who are compelled to work for less. These strategies have helped to create a global economy which is strongly predicated upon the vulnerability of precarious workers and migrants. Everyday abuses within this global economy do not necessarily stand out as exceptional or unusual, because they are built into the logic of larger economic and regulatory systems. The main effect of the COVID-19 pandemic has been to exacerbate, rather than create, patterns of vulnerability.

This Special Issue has four main goals: 1) to better understand the effects of global economic systems and regulations upon precarious workers and migrants; 2) to draw attention to lived experiences within these systems; 3) to explore the relationship between everyday abuses and interventions targeting human trafficking and modern slavery, and 4) to evaluate different attempts to improve the status quo. In pursuit of these goals, we have divided this Editorial into three main sections. The first offers an overview of key political, economic, and regulatory changes to the relationship between workers, migration, and economic systems. The second focuses upon the obstacles and opportunities associated with the emergence of recent high-profile campaigns targeting human trafficking and modern slavery, and contends that there are no perfect policy responses available to protect labour rights. The third outlines the main arguments of our contributors to the Special Issue. 


\section{Workers, Migrants, and Global Economic Systems}

Over the past forty years, economic growth has been coupled with and often predicated upon the deregulation of labour markets. This trend is most strongly associated with the Thatcher and Reagan governments, which took major steps to decrease the size and power of trade unions, reduce public employment, increase labour flexibility, and privatise state-owned businesses. The key features of this agenda were expanded and exported, especially during the 1990s, as economic globalisation accelerated demand for cheap labour and 'just-in-time' production. This has in turn contributed to a global increase in the number of people in insecure employment or dependent self-employment. ${ }^{4}$

The concept of contract 'flexibility' also expanded during this same period, coinciding with the entrance of large numbers of women into the labour market for the first time. In this context, 'flexibility' primarily referred to the ways employers showed themselves to be accommodating of (women's) care work. However, these 'flexible' working arrangements frequently ended up favouring the needs of businesses over workers. ${ }^{5}$ Flexibility is also closely associated with the gig economy, where self-employment and irregular working arrangements are the norm. All kinds of digital tasks are now outsourced to 'microworkers' around the globe. Despite claims that flexible working arrangements are mutually beneficial, these workers typically have 'no job security, in-work benefits, or labour rights, and are very vulnerable to the whims of employers'. ${ }^{6}$ Platforms such as Amazon Mechanical Turk are able to leverage their market position to depress wages and conditions. ${ }^{7}$ Not all digital work is inherently exploitative, but the deck is nonetheless heavily stacked against most workers thanks to the challenges associated with collective organising, competition, jurisdictional challenges, and limited regulation. Similar kinds of dynamics apply in relation to work-on-demand platforms, such as Uber, which connect people willing to do offline tasks, such as cleaning or delivery, with people who will pay them for their services. The vast majority of workers are

4 J Berg et al., Non-Standard Employment Around the World: Understanding challenges, shaping prospects, International Labour Organization, Geneva, 2016, https://www.ilo.org/ wcmsp5/groups/public/---dgreports/---dcomm/---publ/documents/publication/ wcms_534326.pdf.

5 Low Pay Commission, A Response to Government on 'One-sided Flexibility', UK Government, London, 2018, https://assets.publishing.service.gov.uk/government/uploads/system/ uploads/attachment_data/file/765193/LPC_Response_to_the_Government_on_ one-sided_flexibility.pdf.

6 J Webster, 'Microworkers of the Gig Economy: Separate and precarious', New Labor Forum, vol. 25, no. 3, 2016, pp. 56-64, p. 60, https://doi.org/10.1177/1095796016661511.

7 A J Wood et al., 'Networked but Commodified: The (dis)embeddedness of digital labour in the gig economy', Sociology, vol. 53, no. 5, 2019, pp. 931-950, https://doi. org/10.1177/0038038519828906. 
legally classified as independent contractors, but in most cases their activities remain centrally coordinated, remunerated, and 'algorithmically managed'. The terms and conditions offered by work-on-demand platforms have been contested in various ways, including via strike actions in places such as Australia, Brazil, Kenya, and the United States, but there nonetheless remain significant barriers to effective organisation and regulation.?

Labour market deregulation is frequently justified in terms of increasing international competitiveness. Higher wages and regulations are routinely portrayed as a drag on economic performance, while lower wages and less regulation are held up as recipes for superior performance and economic growth. When one country deregulates, other governments can become concerned that they will be disadvantaged unless they follow suit. ${ }^{10}$ For similar reasons, organised labour is frequently viewed as an impediment to competitiveness rather than as a legitimate representation of the interests of workers. Suppressing collective bargaining and worker rights consequently becomes a primary goal of growth-oriented national economic policy, while corporate interests and government policies end up being ever more closely aligned. One particularly stark example of this larger dynamic comes from India, where 'laws related to safety conditions, recognition of trade unions, and legal working hours' were recently suspended in many jurisdictions for a three-year period to help promote economic growth following COVID-19. ${ }^{11}$ Another increasingly popular strategy for further reducing wages and conditions is to draw upon migrant labourers and labour intermediaries, since migrant labourers - both documented and undocumented — tend to have less bargaining power than their local peers, while intermediaries help create a

8 K Vandaele, 'Will Trade Unions Survive in the Platform Economy? Emerging patterns of platform workers' collective voice and representation in Europe', Working Paper, European Trade Union Institute, 2018, https://www.etui.org/sites/default/files/ Working $\% 20$ Paper $\% 202018.05 \% 20$ Vandaele $\% 20$ Trade $\% 20$ unions $\% 20$ Platform $\% 20$ economy $\% 20$ Web.pdf.

9 See, for example, A L Dahir, 'Uber and other ride-hailing apps are facing a major test in Kenya-from drivers themselves', Quartz. Africa, 13 July 2018, https://qz.com/ africa/1327568/uber-taxify-little-cab-kenya-drivers-end-strike.

10 See, for example, Z Wang, 'Economic Competition, Policy Interdependence, and Labour Rights', New Political Economy, vol. 23, no. 6, 2018, pp. 656-673, https://doi. org/10.1080/13563467.2018.1384452; K A Elliott, 'Labor standards', in K A Reinert (ed.), Handbook of Globalisation and Development, Edward Elgar, London, 2017, pp. 183-198.

11 A Bhat, 'Suspension of Indian Labor Laws to Hurt Low-Income Workers', The Diplomat, 23 June 2020, https://thediplomat.com/2020/06/suspension-of-indianlabor-laws-to-hurt-low-income-workers. 
legal regime where workers are no longer employed directly. ${ }^{12}$

Many attempts have been made to classify and explain this evolving world of work. Guy Standing, for example, has theorised 'the creation of a global "precariat", which he portrays as an emerging class within the global economy that is collectively defined by a shared lack of labour-related security. ${ }^{13}$ While there is broad agreement that vulnerability and insecurity are foundational themes, Standing's critics have questioned the extent to which this singular framework smooths over differences in context and circumstances. One major line of critique has been that Standing 'contrasts precarious work with a non-precarious past defined by stable employment, welfare provisions and other features of Northern countries' histories which are virtually unknown in the history of Southern countries'. ${ }^{14}$ In most parts of the world informal work has long been the norm, rather than the exception. ${ }^{15}$ This means that local experiences of work and political organising can easily get lost or distorted when viewed against idealised Eurocentric benchmarks.

Further concerns have also been raised about the portrayal of the precariat as a singular class, since this can obscure numerous differences and divisions that are difficult to capture in class terms. As Louise Waite has observed, precarity can be 'conceived as both a condition and a possible point of mobilisation among those experiencing precarity'. ${ }^{16}$ Transitioning from class to condition is more than a semantic exercise, since it helps to underscore the need for a less reductive and more relational approach, where precarity primarily appears as a 'method of inquiry that asks how unstable work relates to fragile conditions of life in

12 See, for example, P Deshingkar, 'The Making and Unmaking of Precarious, Ideal Subjects-Migration brokerage in the Global South', Journal of Ethnic and Migration Studies, vol. 45, no. 14, 2019, pp. 2638-2654, https://doi.org/10.1080/136918 3X.2018.1528094; H Shamir, "The Paradox of "Legality": Temporary migrant worker programs and vulnerability to trafficking', in P Kotiswaran (ed.), Revisiting the Law and Governance of Trafficking, Forced Labor and Modern Slavery, Cambridge University Press, Cambridge, 2017.

13 G Standing, The Precariat: The new dangerous class, Bloomsbury, New York, 2011.

14 B Scully, Precarity North and South: A southern critique of Guy Standing', Global Labour Journal, vol. 7, no. 2, 2016, pp. 160-173, p. 161, https://doi.org/10.15173/glj. v7i2.2521. See also R Munck, 'The Precariat: A view from the South', Third World Quarterly, vol. 34, no. 5, 2013, pp. 747-762, https://doi.org/10.1080/01436597.2013 .800751 .

15 See, for example, M Chen and F Carré, The Informal Economy Revisited: Examining the past, envisioning the future, Routledge, London, 2020.

16 L Waite, 'A Place and Space for a Critical Geography of Precarity?', Geography Compass, vol. 3, no. 1, 2009, pp. 412-433, p. 413 (italics in original), https://doi.org/10.1111/ j.1749-8198.2008.00184.x. 
particular times and places'. ${ }^{17}$ Accordingly, precarious work tends to intersect with and be further magnified by the effects of other factors, such as housing and health, public safety and private violence, and unemployment. Recent events in the United States have demonstrated yet again that structural racism cuts across class considerations, creating forms of precarity that are not reducible to socio-economic status.

More issues emerge when precarity is viewed as a platform for mobilisation. The first major sticking point here is the degree to which shared experiences of vulnerability, exploitation, and oppression translate into feelings of solidarity and common purpose. As theories of labour market competition have explored at length, workers are typically positioned in competition with their peers for work, advancement, and relative security. One obvious example here is the stigma and strain associated with unemployment, which can generate strong pressures to secure paid employment, no matter how precarious, especially in situations where social safety nets are either weak or weakening. ${ }^{18}$ This competition impedes collective action, as potential bonds of solidarity are complicated by individual calculations. These challenges tend to be exacerbated by subcontracting, outsourcing, and tied migration schemes, which create further barriers to organising.

Labour market competition amongst precarious workers can also complicate efforts to sharply distinguish between free and forced labour. As Judy Fudge has argued, liberal accounts of labour markets as arenas 'of free exchange in which legally equal parties contract to their own mutual advantage' tend to obscure all the ways in which vulnerable individuals negotiate from legally enshrined positions of disadvantage ${ }^{19}$ Personalised forms of coercion, such as violence, debt, and threat, typically take place within larger structural contexts of precarity, insecurity, and competition amongst workers. Shared experiences of vulnerability and exploitation can sometimes create a valuable platform for collective mobilisation, but it can also be very difficult to mobilise effectively due to the effects of labour market competition and segmentation. The global economy is organised in ways that tend to leave precarious workers divided, rather than united.

17 K M Millar, 'Toward a Critical Politics of Precarity', Sociology Compass, vol. 11, no. 6, 2017, pp. 1-11, p. 5, https://doi.org/10.1111/soc4.12483.

18 There are also further dynamics associated with wage labour relative to subsistence labour, including mixed livelihood strategies, but we cannot go into detail on this topic here.

19 J Fudge, 'Modern Slavery, Unfree Labour and the Labour Market: The social dynamics of legal characterization', Social \& Legal Studies, vol. 27, no. 4, 2017, pp. 414-434, p. 419, https://doi.org/10.1177/0964663917746736. 
This Special Issue brings together these related issues under the rubric of everyday abuses within the global economy. Our approach is chiefly concerned with the design and operation of global economic and regulatory systems, and with the ways in which these intersecting systems create conditions that pave the way for vulnerability, precarity, and insecurity for both workers and migrants. We contend that increasingly integrated systems governing work and migration have had important effects on lived experiences of work, the regulation of that work, and the capacity of workers to effectively organise in support of political and economic change. We do not presume that informality and precarity are distinctively new phenomena. Instead, we focus upon how, where, and why experiences of precarity and informality have been reconfigured. Precarious workers within the global economy may not constitute a coherent and singular class, but many of their experiences and conditions can at least partially be explained and analysed in terms of recurring constraints, regulatory models, and economic dynamics.

Everyday abuse, as we understand it, refers to a wide range of lived experiences. By speaking in terms of the everyday, we seek to draw 'attention to a wide variety of practices, subjects, relations, [and] things that usually would not feature in political analysis'. ${ }^{20}$ We are particularly concerned here with day-to-day and frequently mundane experiences associated with precarious work, which can be usefully described in terms of 'sociologies of the unnoticed'. ${ }^{21}$ Most forms of everyday abuse taking place within the global economy do not stand out as unusual or exceptional. They instead comprise the largely unnoticed products of the regular and intended operations of larger economic and regulatory systems. We therefore need to understand abuse as more than egregious violations of applicable laws by corrupt, criminal, and/or cruel individuals. It is undoubtedly preferable to work for a kind employer rather than a cruel employer, but having a relatively kind employer does not necessarily provide sufficient protection against everyday abuse.

Workers experiencing everyday abuses rarely regard themselves as victims in need of rescue, but their capacity to defend their interests tends to be heavily constrained. Take, for example, the issue of global supply chains, through which over 80 per cent of global goods and services are now traded. ${ }^{22}$ One crucial feature of supply chains is the disproportionate power exercised by lead firms at the head of the chain, especially in the case of multinationals. As

20 X Guillaume and J Huysmans, 'The Concept of "the Everyday": Ephemeral politics and the abundance of life', Cooperation and Conflict, vol. 54, no. 2, 2019, pp. 278-296, p. 285, https://doi.org/10.1177/0010836718815520,

${ }^{21} \mathrm{M} H$ Jacobsen, Encountering the Everyday: An introduction to the sociologies of the unnoticed, Red Globe Press, Basingstoke, 2009, pp. 1-41.

22 Ford Foundation, Quality Work Worldwide: An exploration of trends and strategies for transformative change, Ford Foundation, 2018, p. 2. 
Mark Anner has demonstrated, 'trade rules, technology and financialization have contributed to growing power asymmetries ... which have deleterious effects on workers: a price squeeze and a sourcing squeeze'. ${ }^{23}$ In the case of prices, this involves lead firms using their power to pressure their suppliers to depress wages and increase production targets. In the case of sourcing, lead firms use their clout to insist on accelerated production cycles and flexible order volumes, frequently obliging factories down the chain to resort to forced overtime and further subcontracting to accommodate quick and sharp fluctuations in demand. These business models do not exist in a vacuum, but are both legitimated and enabled by government (in)actions, raising challenging questions about the relationship between private and public governance. ${ }^{24}$

This brings our analysis back to the issue of state attitudes towards labour and the ways they (do not) regulate global and domestic supply chains. We cannot go into all of the relevant issues in depth here, but several key points need to be highlighted. At the top of the list is labour inspection. In many cases, public scrutiny of workplaces has struggled to keep pace with the changing nature of work, working relationships, and declining rates of unionisation. ${ }^{25}$ Both the number of labour inspectors and frequency of inspections has declined in many jurisdictions, and their mandate tends to be complicated by other considerations, such as immigration enforcement and a lack of effective sanctions. This decline in labour inspections has also taken place alongside the proliferation of voluntary business compliance protocols, which are designed to encourage rather than enforce compliance. The many problems with selfregulation have been repeatedly documented, yet voluntary compliance and corporate social responsibility nonetheless continue to be widely championed. This continued support for a model which has such a consistently poor track record can be primarily traced to its political value as a strategy for deflecting calls for forms of public regulation less favourable to corporate interests.

Deregulation is usually said to involve the state getting 'out of the way' of the market, but this ideological formula has long suffered from a wilful blindness regarding the indispensable role played by states in both creating and sustaining markets in the first place. This role is especially pronounced when it comes to tied migrant labour schemes, where government regulations determine the criteria

23 M Anner, 'Squeezing Workers' Rights in Global Supply Chains: Purchasing practices in the Bangladesh garment export sector in comparative perspective', Review of International Political Economy, vol. 27, no. 2, 2020, pp. 320-347, https://doi.org/10.10 80/09692290.2019.1625426.

24 See, for example, R M Locke, The Promise and Limits of Private Power: Promoting labor standards in a global economy, Cambridge University Press, Cambridge, 2013.

25 ILO, 'Strategic Compliance Resource Page', ILO, Geneva, 2018, https:/ /www.ilo.org/ global/topics/labour-administration-inspection/resources-library/training/ WCMS_620987/lang--en/index.htm. 
and conditions that govern when migrants can travel, where and how they are permitted to work and live, how long they are allowed to stay, and what kinds of rights and protections they are ultimately entitled to. Tied and circular migration schemes have rapidly expanded globally, with migrants growing strawberries in Spain, tomatoes in Canada, and building skyscrapers in the United Arab Emirates. None of this would be feasible without governments creating and sustaining these labour markets. Policies to deter certain kinds of migration typically operate alongside other policies which promote large volumes of migrant labour on restrictive terms. ${ }^{26}$ At both a national and international level, conversations about migration management have increasingly centred around efforts to regulate migration in ways which enable both sending and receiving states to extract profit from migrants. According to the International Labour Organization, there were roughly 164 million migrant workers globally in 2017, with '111.2 million (67.9 per cent) employed in high-income countries'. ${ }^{27}$ While the challenges facing undocumented migrants are well known, comparatively little attention has been paid to the forms of everyday abuse associated with documented migration. Most abuses within the global economy primarily take place because of - rather than in spite of - existing economic and regulatory systems. It should also be clear, moreover, that these systems are hard to change, since economic and political elites benefit from their operations. While some voices and organisations have continued to champion the cause of migrant and worker rights, other voices have gravitated towards a new political cause.

\section{Diversions and Distractions? Modern slavery and human trafficking}

Most of the issues we have identified above are much broader in scope than more familiar concerns associated with human trafficking or modern slavery. We could have followed established conventions by treating human trafficking as our primary starting point, and then attempted to build outwards to discuss how these other issues relate to trafficking. Instead, we made a conscious decision to start with everyday abuses within the global economy, and to then go on to consider where and how human trafficking might fit within this

26 See, for example, J Quirk and D Vigneswaran, 'Mobility Makes States', in D Vigneswaran and J Quirk (eds.), Mobility Makes States: Migration and power in Africa, Pennsylvania University Press, Philadelphia, 2015, pp. 1-36; L Martin, 'Carceral Economies of Migration Control', Progress in Human Geography, 2020, https://doi. org/10.1177/0309132520940006.

$27 \mathrm{~N}$ Popova and M H Özel, ILO Global Estimates on International Migrant Workers, International Labour Office, Geneva, 2018, p. ix, https://www.ilo.org/wcmsp5/ groups/public/---dgreports/---dcomm/---publ/documents/publication/ wcms_652001.pdf. 
picture. This overall approach is informed by a number of considerations. Firstly, and perhaps most obviously, we have questions of relative scale. Everyday abuses are integral to the lives of hundreds of millions of people throughout the globe, while practices which fall under the labels of human trafficking and modern slavery constitute a small subset within this larger whole. Secondly, the practices and systems creating the conditions that enable everyday abuses tend to be the same practices and systems that also enable the kinds of extreme abuses associated with human trafficking and modern slavery. It is not always possible to sharply separate human trafficking from everyday abuses, and problems arise when the former is singled out while the latter is pushed to the margins. Finally, the majority of trafficking interventions focus upon individual cases, rather than systems, thereby undermining their capacity to prevent and correct patterns of abuse arising from the smooth and regular operations of the global economy.

Human trafficking, as established within the framework of the United Nations Convention against Transnational Organised Crime, is predominantly understood as a criminal justice issue. In the early 2000s, most interventions focused on brothel raids by police units, reflecting a specific concern with commercial sexual exploitation, which has long been argued to have overshadowed potential investments in other spheres. ${ }^{28}$ In recent years, however, attention has broadened and law enforcement officers regularly raid various businesses, such as farms, fishing vessels, and construction sites. One critique of this criminal justice approach is that it has involved 'raid and rescue' type responses, arresting criminals and rescuing victims, who are placed in support centres and, in some cases, enforced rehabilitation. By their very nature, criminal justice responses are not community-led, so interventions are carried out by external actors rather than driven by affected workers. This has contributed to a range of problems. ${ }^{29}$ As this example demonstrates, the rapid elevation of human trafficking and latterly modern slavery to the front ranks of global policy conversations has created both opportunities and obstacles. Some organisations and campaigners focusing on issues relating to migrant and worker rights have taken advantage of the new funding streams, alliances, and access points associated with increasing global interest around trafficking and slavery. Others have used trafficking and slavery as a means of limiting the rights of workers, speaking on their behalf, and offering silver bullet solutions to complex and deeply political problems.

28 See, for example, L M Agustín, Sex at the Margins: Migration, labour markets and the rescue industry, Zed Books, London, 2007.

29 See, for example, E Bernstein, Brokered Subjects: Sex, trafficking and the politics of freedom, University of Chicago Press, Chicago, 2018; and L Barnes, 'Live-Tweeting and Distant Suffering: Nicholas Kristof as global savior', Humanity: An International Journal of Human Rights, Humanitarianism, and Development, vol. 11, no. 2, 2020, pp. 147-164, https://doi. org/10.1353/hum.2020.0021. 
Efforts to promote and protect worker and migrant rights have been strongly affected by the emergence of the political cause of ending human trafficking and modern slavery. Jackie Pollock, who worked in the 2000s at the MAP Foundation in Chiang Mai, Thailand, used to regularly use her rectangular office table to demonstrate the true scale of the human trafficking problem. She would draw a narrow slice at one end representing human trafficking, then show workers who suffered single or multiple labour abuses filling the wide middle, and finally show a thin slice representing those who were enjoying their labour rights at the other end of the table. The people that came through MAP's assistance centres, Jackie would frequently say, almost exclusively came from the middle of the table. Her point, rooted in years assisting workers at the MAP Foundation and working with sex workers at Empower Foundation, was that human trafficking happens in a context of widespread everyday labour abuses. ${ }^{30}$ She also took pains to point out the great elephant in the anti-trafficking room: most of the suffering experienced at work is not human trafficking and could be addressed by allowing workers to organise and form unions; but this is seen as more threatening than treating people as helpless victims. Thus, many organisations working in the field of labour rights, activism, and support have found that the space for labour rights has shrunk as the anti-trafficking space has grown. ${ }^{31}$ This in turn risks creating a hierarchy of victims, ${ }^{32}$ where those who are labelled 'trafficked persons' become worthy of attention and support, while others who endure everyday labour abuses are instead positioned outside intervention efforts, since they are not considered 'victim enough'.

When editing this Special Issue of Anti-Trafficking Review we found that contributions frequently railed against the anti-trafficking or, more commonly, the modern slavery frameworks. The anti-trafficking framework was enshrined in international law by the United Nations Trafficking Protocol in 2003. It has subsequently been widely ratified and, by 2018, had inspired 168 countries to develop national legislation criminalising human trafficking. ${ }^{33}$ The concept of

30 This concept was later documented in: Global Alliance Against Traffic in Women, Beyond Borders: Exploring links between labour and trafficking, GAATW, Bangkok, 2010, https://www.gaatw.org/publications/WP_on_Labour.pdf.

31 See M Dottridge (ed.), Collateral Damage: The impact of anti-trafficking measures on buman rights around the world, GAATW, Bangkok, 2007, http://www.gaatw.org/Collateral\%20 Damage_Final/singlefile_CollateralDamagefinal.pdf.

32 R Haverkamp, 'Victims of Human Trafficking: Considerations from a crime prevention perspective', in C Lernestedt, E Herlin-Karnell and R Haverkamp (eds.), What is Wrong with Human Trafficking? Critical perspectives on the law, Bloomsbury Publishing, London, 2019.

33 J-L Lemahieu et al., Global Report on Trafficking in Persons, United Nations Office on Drugs and Crime, Vienna, 2018, p. 45, https://www.unodc.org/documents/data-andanalysis/glotip/2018/GLOTiP_2018_BOOK_web_small.pdf. 
modern slavery has been used in popular discourse from the 1990s, but only entered the realm of public policy in the United Kingdom (UK) following the publication of a 2013 report entitled It Happens Here by the Centre for Social Justice (CSJ), a right-wing think tank. This report defined modern slavery as an umbrella term encompassing human trafficking, forced labour, slavery, and servitude. ${ }^{34}$ It was attributed by then UK Home Secretary Theresa May as serving as a 'catalyst' for the UK Modern Slavery Act of $2015 .{ }^{35}$ Importantly, the 2013 CSJ report looked closely at the potential for a focus on global supply chain governance to sit alongside the UK interest in reducing labour regulations and cutting labour inspection capacity, whilst shifting the focus towards corporate self-governance. ${ }^{36}$ In this regard, the modern slavery agenda not only served to divert attention towards decent work deficits in global supply chains, but also distracted from the UK's weakened labour rights protection framework by developing a high-profile response to modern slavery.

Not all cases follow the same pattern, however. In contrast to the UK experience, where the deregulation agenda preceded a strong interest in modern slavery as a diversionary tactic, recent attacks on labour rights in Brazil have instead been defined by a direct attack upon existing anti-slavery laws to help pave the way for deregulation. The Bolsonaro government is currently in the process of deregulating major production sectors, diminishing the power and resources of their labour inspectorate, and directly attacking collective bargaining. ${ }^{37}$ These efforts have undermined a long-term campaign Brazil has fought against work analogous to slavery. This commenced in the mid-1990s and was widely presented as a positive example of a country harnessing the language of slavery to challenge labour rights abuses in supply chains, hold lead firms to account, and ensure workers were awarded compensation. For President Bolsonaro, these anti-slavery protections now risk reducing Brazil's trade competitiveness and the national economy. ${ }^{38}$

34 Centre for Social Justice (CSJ), 'It Happens Here: Equipping the United Kingdom to fight modern slavery', CSJ, London, 2013, p. 4, https://www.centreforsocialjustice. org.uk/core/wp-content/uploads/2016/08/CSJ_Slavery_Full_Report_WEB5.pdf.

35 CSJ, 'Major CSJ recommendation - the Modern Slavery Act - gains Royal Assent', Press release, 26 March 2015, https://www.centreforsocialjustice.org.uk/core/wpcontent/uploads/2016/08/CSJ_press_release-Modern_Slavery-26_03_15.pdf.

36 CSJ, 2013, p. 26.

37 'How Big Beef and Soya Firms Can Stop Deforestation', The Economist, 11 June 2020, https://www.economist.com/the-americas/2020/06/11/how-big-beef-and-soyafirms-can-stop-deforestation.

38 'How Brazilian Law Defines Labour Analogous to Slavery', Conectas, 8 May 2019, https://www.conectas.org/en/news/how-brazilian-law-defines-labour-analogous-toslavery. 
Until relatively recently, Brazilian campaigns against forced labour were widely celebrated, but its model was not really emulated by other governments. This can be contrasted with the UK example, where Theresa May helped popularise the term modern slavery and its related paradigm around the world. Other countries have recently embraced the UK model, such as Canada and Australia. Modern slavery did not start with Theresa May, but she did play a pivotal role in ensuring that modern slavery was officially embraced and internationally shared as a political strategy by the UK government.

Both the human trafficking and modern slavery paradigms have this in common: they are frequently used by governments as a political cover for the harms perpetrated against migrant workers. As Julia O'Connell Davidson observed in 2010:

anti-trafficking discourse calls on us to condemn as 'modern slavery' the application of coercive pressures on migrants without state sanction, but simultaneously to endorse the application of ever more coercive pressures on migrants by states, often in the name of protecting them from 'modern slavery' ${ }^{39}$

The potency of modern slavery stems in part from the inaccurate parallels that are often drawn with the transatlantic slave trade. Furthermore, its amorphous nature outside of the UK legal context makes this particular term both highly attractive and deeply problematic. This is demonstrated by the wide array of actors and agencies that seek to engage with modern slavery, either to popularise its use or to decry its widespread application. Interestingly, both sides serve a common cause in further raising the profile of the term. However, there is currently scant information regarding the independent effects of modern slavery, for better or worse, on specific government approaches. Would governments have acted differently if modern slavery did not exist, or is this concept merely deployed in order to make deregulation and anti-immigration measures more palatable to key constituencies?

The most significant recent example of the politics of slavery and trafficking in action revolves around the use of these paradigms in order to further an anti-migrant agenda. This is not a new issue. When the Global Alliance against Traffic in Women (GAATW) published The Migrating Women's Handbook in 1999, it noted how:

39 J O'Connell Davidson, 'New Slavery, Old Binaries: Human trafficking and the borders of "freedom", Global Networks, vol. 10, issue 2, pp. 244-261, p. 255, https://doi. org/10.1111/j.1471-0374.2010.00284.x. 
Unfortunately, most countries do not aggressively protect the rights of migrant workers, and it is left to workers themselves and NGOs to ensure that migrant workers are not exploited and abused in their work. ${ }^{40}$

This frustration at the absence of tools to draw upon to support migrant women when they were abused and exploited during their journey led some feminists to advocate for greater protections in international law. ${ }^{41}$ Through a human rights-based approach to human trafficking, they helped to ensure access to justice for trafficked persons, as well as tailored support, pre-departure advice, and measures to promote self-organising so that trafficked persons have a voice in anti-trafficking responses. One of the consequences of this advocacy is that there is now a wide gap between the support and remedies available to migrant workers subjected to human trafficking compared to those suffering other types of labour abuses. The questions this Special Issue seeks to address are what practical impact this chasm has on workers, what challenges this siloed approach poses, and whether the clock should be rewound to 1999 so that a better solution can be found.

Since the publication of Collateral Damage, which was the first review of government responses to the UN Trafficking Protocol, there have been moves by policy makers to highlight the link between exploitation and widespread abuse. The ILO Forced Labour Protocol of 2014 requires states to take steps to prevent forced labour. This includes ensuring the application of labour law to all workers in all sectors, strengthening labour inspection, preventing abuses in recruitment, and 'supporting due diligence' by the private sector. At the national level, some governments are also adopting alternative approaches to antitrafficking, which include acknowledging that cases of severe exploitation falling under the human trafficking definition constitute just one of many workplace harms. The Scottish Government's Fair Work Action Plan ${ }^{42}$ offers an example of an effort to tackle these issues, establishing a range of public, social, and private governance measures in order to achieve 'fair work' throughout the economy by

40 GAATW, The Migrating Women's Handbook, GAATW, Bangkok, 1999, p. 7, http:/ /www. gaatw.org/books_pdf/migrating_woman_handbook.pdf.

41 See M Wijers, 'Purity, Victimhood and Agency: Fifteen years of the UN Trafficking Protocol', Anti-Trafficking Review, issue 4, 2015, pp. 56-79, https://doi.org/10.14197/ atr.20121544.

42 See Fair Work Action Plan, n.d., https://economicactionplan.mygov.scot/fair-work. 
2025. ${ }^{43}$ The framework is overseen by the Minister for Business, Fair Work and Skills and requires action by employers, supports and promotes trade unions, and establishes specific guidance for high-risk labour sectors. Alongside this the government has taken progressive practical steps to protect migrant workers within their devolved competences, including instituting a firewall between National Health Service Scotland and immigration enforcement to prevent the sharing of information. This is not labelled as an anti-trafficking response, but the Scottish government is seeking to create strong foundations to its labour market in order to prevent both everyday abuse and extreme exploitation.

The Scottish government's less public relations-oriented response to labour abuse and exploitation, and others like it by countries ranging from Spain to Sweden and New Zealand, do not receive the level of critique and celebration as those responses labelled modern slavery or human trafficking. Advocates, academics, authors, and activists could also challenge their own tunnel vision in this area and engage with and debate broader, labour rights-focused, lowerprofile government agendas. In a prescient piece published for the 2020 World Day Against Trafficking in Persons, Bandana Pattanaik observed how 'antitrafficking measures will be more effective if we recognise their strengths and limitations'. ${ }^{44}$

Could it be that, in seeking to complexify and critique anti-trafficking, we are at risk of over-simplifying the alternative? Each policy avenue has its pitfalls. They are all messy. The route to success is never reached through a single solution but by taking many bumpy paths simultaneously-small steps forward and some steps backward. This collection of articles serves to underline this dilemma. It presents case studies of people seeking solutions to complex problems, highlights the 'collateral damage' caused by policy interventions, and demonstrates the need for policy to keep pace with change.

\section{This Special Issue}

The articles featured in this Special Issue come at the topic of everyday abuse from a variety of angles. Leanne McCallum leads with a fascinating account of how opportunities for exploitation were both created and combatted in New

43 Fair work is defined as 'work that offers effective voice, opportunity, security, fulfilment and respect; that balances the rights and responsibilities of employers and workers and that can generate benefits for individuals, organisations and society', see Fair Work Convention, Fair Work Framework, 2016, https://www.fairworkconvention.scot/wpcontent/uploads/2018/12/Fair-Work-Convention-Framework-PDF-Full-Version. pdf.

44 B Pattanaik, 'Can Anti-Trafficking Measures Stop Trafficking?', GAATW, 29 July 2020, https://gaatw.org/blog/1057-can-anti-trafficking-measures-stop-trafficking. 
Orleans in the aftermath of Hurricane Katrina in 2005. In a bid to accelerate recovery, the US government suspended key labour protections and oversight mechanisms, thereby enabling employers to further erode incomes and working conditions. The inevitable abuses that followed put wind into the sails of both the worker rights and the anti-trafficking movements in Louisiana. However, their markedly different approaches undercut potential alliances and collaborations. McCallum argues that the anti-trafficking movement received far more funding and official support, but its focus on criminal justice and its close relationship with law enforcement undercut relationships with workers seeking to counter abusive labour practices. The worker rights movement, by contrast, developed a multi-ethnic coalition between migrant and African-American workers grounded in shared experiences of labour abuse post-Katrina. McCallum concludes with lessons that the post-Katrina past might hold for the post-COVID-19 future.

Following this, Benjamin Harkins proposes shifting interventions to counter exploitation away from human trafficking and modern slavery and towards the everyday abuse of wage theft. Since wage theft is one of the most common forms of labour abuse, Harkins argues that migrant workers can more easily identify with not being paid than with being labelled as 'trafficking victims'. Interventions designed to recover lost wages and reduce the likelihood of wage theft thus not only represent a pragmatic, migrant-oriented response to a concrete problem. They also seek to address the inequitable distribution of resources that sits at the heart of neoliberal globalisation.

The next four articles investigate specific experiences of everyday abuse. Ella Parry-Davies sets the scene with a series of intimate and innovative soundwalks recorded with Filipinx domestic workers in the United Kingdom and Lebanon. These explore the slow grind of constant work, endless repetition, and routine abuse characterising these women's lives alongside their resistance to employers' overbearing demands. She argues that the twin spectacular narratives of 'modern hero' and 'modern slave' - which underpin labour export policies in the Philippines as well as anti-trafficking interventions in Lebanon and the UKinvisibilise the mundane reality of life as Filipinx overseas domestic workers and, in doing so, prevent a policy response to the abuses they experience.

Bama Athreya turns the light on the digital surveillance, information asymmetries, and algorithmic cruelty found within the gig economy. Her article examines the experiences of gig workers on platforms for ride-sharing and domestic work, as well as with one job aggregator. Drawing upon interviews with workers in multiple countries, she finds that gig work platforms tend to exacerbate the existing power asymmetries between employers and workers while adding new elements of control and exploitation. These include customer ratings that trigger automatic account suspensions, obscure algorithms that decide which workers receive better gigs, and unpaid 'data labour'. Importantly, Athreya points to the need to rethink the meanings of force, fraud, and coercion 
in the gig economy, especially given its exponential growth.

\begin{abstract}
Abigail Hunt and Emma Samman investigate platform-based domestic work in South Africa. They are particularly interested in how the business model of 'gigs' makes avoiding employment regulation an implicit part of the business proposition which platforms offer to their clients. They acknowledge that people working for platforms often have good intentions, that workers see certain advantages over the 'traditional' domestic work labour market, and that in South Africa job offers, even when exploitative, are often welcomed by the people accepting them. Nevertheless, they argue that the toxic combination of platforms' popularity and their reliance on regulatory avoidance for their operations threatens to undermine or exclude workers from legislative advances in this sector.
\end{abstract}

Frederico Parra introduces and analyses the world of waste picker activism in Colombia. He chronicles the twists and turns of how marginalised and informal waste pickers successfully organised to protect themselves and their livelihoods from neoliberalising policies and the state-backed privatisation of public services. Through strategic and repeated use of the Constitutional Court they achieved recognition as workers providing a public service, remuneration from end users (households), and sheltered access to recyclable waste. However, none of these gains are secure and they continue to be challenged on various fronts. Parra concludes that there is a fundamental tension between the protection of livelihoods for marginalised groups and neoliberalisation, and that the former is only possible if steps are taken to rein in the latter.

The last thematic article brings us full circle by presenting readers with another tale of two initiatives: one grounded in modern slavery and another in worker solidarity. Focusing upon interventions in India, Lorena Arocha, Meena Gopal, Bindhulakshmi Pattadath, and Roshni Chattopadhyay trace NGOs' attempts to emancipate bonded labourers in stone quarries by getting them officially recognised as bonded labourers, organising them into selfhelp groups, and then helping these groups to apply for independent mining leases. However, these efforts were largely unsuccessful, since the groups were inadequately prepared to either run their own mines or to withstand the state-backed encroachment of large mining concerns into their area. The authors contrast these events with the evolution of one waste pickers' movement. Primarily comprising Dalit women, this initiative was worker-led from the start and centred on —as with Parra above — protecting their area of work from stateled privatisation. It involved organisation into collectives and the articulation of a collective identity, as well as the cultivation of allies when needed to challenge forces greater than themselves. By contrasting the 'ways of seeing' associated with these two different approaches, they reveal how different diagnoses of similar kinds of problems-modern slavery or worker solidarity-shape the terms of political engagement. 
These full-length research articles are followed by five responses in the Debate Section of this Special Issue. The debate statement we proposed was explicitly political: 'It is worth undermining the anti-trafficking cause in order to more directly challenge the systems producing everyday abuses within the global economy'. This question was designed to foreground the strategic and tactical considerations which influence how and why different organisations navigate the complex mixture of opportunities and problems associated with the rapid growth of efforts to combat human trafficking. How strong is the tactical case for attempting to ride the anti-trafficking wave, despite the now well-known problems, if anti-trafficking can help to amplify political arguments, secure funding streams, and facilitate access to power? Or are the problems associated with trafficking interventions now so fundamental that it has become necessary to embrace alternative forms of organisation and engagement which call into question the viability and legitimacy of the anti-trafficking cause? Is it better to stay in or opt out? Does this really boil down to a binary choice?

The majority of contributors to this debate, perhaps unsurprisingly, reject the zero-sum framing of the statement and instead argue for the third way of reform. Ella Cockbain argues that campaigns against human trafficking and against everyday abuse are not necessarily incompatible, and suggests that they could complement each other if anti-trafficking spaces became more inclusive and 'some of anti-trafficking's most positive aspects ... migrate from the margins to the mainstream'. Sienna Baskin and Huey Hewitt highlight how exceptionalising and individualising narratives of traffickers and victims frequently do damage while taking activists' eyes off the ball when it comes to systemic change. However, like Cockbain, they too find that corners of the anti-trafficking field have evolved to embrace a wider lens and a more critical perspective. They argue that this offers a path to creating a more comprehensive anti-trafficking movement that agitates against extreme and everyday exploitation simultaneously. Kate Roberts turns this strain of argument around using the lens of Overseas Domestic Worker visas in the UK. Instead of calling for a more comprehensive movement, she insists that the two causes are inseparable: 'antitrafficking responses will only be effective when they ... includ[e] addressing the systems which produce everyday abuse'.

The two remaining contributions solidly declare themselves in favour of the debate's central proposition: topple anti-trafficking to refocus on everyday abuse. Alison Clancy and Frances Mahon, writing from the perspective of a sex worker-led organisation in Canada, explain how their past engagements with anti-trafficking interventions have led them to conclude that the 'human trafficking discourse in Canada is used [...] to legislate, limit and curtail the activities of sex workers'. Having concluded that anti-trafficking cannot be reformed, they are now seeking to improve access to rights for im/migrant sex workers by mounting a constitutional challenge against regulations prohibiting 
temporary residents from providing paid sexual services in Canada. Finally, Lisa Rende Taylor details the summary lessons of thousands of interactions between the Issara Institute and businesses over claims of abuse of migrant workers in Thailand. She has seen where remedy is possible and where, all too often, it gets lost amidst excuses and other priorities. She sees directly challenging systems of everyday abuse as a moral imperative for the field and admits that 'the anti-trafficking community needs to let go of the dream of governments solving the problem of human trafficking by putting exploiters behind bars'.

These divergent responses to this Special Issue help to underscore the complexity of the underlying structural issues at stake, including the governance of migration, global commerce, labour market deregulation, human rights, social justice, and decent work. They also help to underscore the fact that there is never going to be a singular or straightforward solution to the problems associated with everyday abuse and extreme exploitation. It is instead necessary to take into account the way in which specific constraints, opportunities, and strategies inform our diagnosis and understanding of the problem.

Joel Quirk is a Professor of Politics at the University of the Witwatersrand, South Africa. His research focuses upon slavery and abolition, human mobility, social movements, repairing historical wrongs, and the politics and history of Africa.Email: joel.quirk@wits.ac.za

Caroline Robinson is an independent consultant based in Scotland. She co-founded the UK-based charity Focus on Labour Exploitation (FLEX) in 2012 and served as its Chief Executive Officer until 2019. She previously led global advocacy for the Global Alliance Against Traffic in Women, co-founding the Anti-Trafficking Review in 2011. She holds an MA in Development Studies with distinction from the Institute of Development Studies. Email: caroline@ csrobinson.co.uk

Cameron Thibos is co-founder and Managing Editor of Beyond Trafficking and Slavery on openDemocracy, as well as Research Fellow on the WorkFREE project at the University of Bath. He previously worked as a Research Associate at the Migration Policy Centre at the European University Institute in Florence, Italy. He holds a d.phil ( $\mathrm{PhD})$ in International Development from the University of Oxford. Email: cameron.thibos@opendemocracy.net 